\title{
Comparing impacts of climate change on streamflow in four large African river basins
}

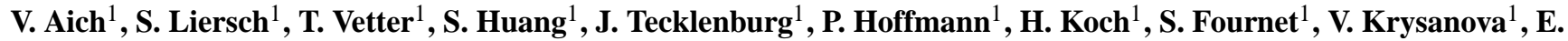 \\ N. Müller ${ }^{2}$, and F. F. Hattermann ${ }^{1}$ \\ ${ }^{1}$ Potsdam Institute for Climate Impact Research, Potsdam, Germany \\ ${ }^{2}$ Institute of Earth and Environmental Science, University of Potsdam, Potsdam, Germany
}

Correspondence to: V. Aich (aich@pik-potsdam.de)

Received: 15 August 2013 - Published in Hydrol. Earth Syst. Sci. Discuss.: 1 November 2013

Revised: 7 February 2014 - Accepted: 22 February 2014 - Published: 4 April 2014

\begin{abstract}
This study aims to compare impacts of climate change on streamflow in four large representative African river basins: the Niger, the Upper Blue Nile, the Oubangui and the Limpopo. We set up the eco-hydrological model SWIM (Soil and Water Integrated Model) for all four basins individually. The validation of the models for four basins shows results from adequate to very good, depending on the quality and availability of input and calibration data.

For the climate impact assessment, we drive the model with outputs of five bias corrected Earth system models of Coupled Model Intercomparison Project Phase 5 (CMIP5) for the representative concentration pathways (RCPs) 2.6 and 8.5. This climate input is put into the context of climate trends of the whole African continent and compared to a CMIP5 ensemble of 19 models in order to test their representativeness. Subsequently, we compare the trends in mean discharges, seasonality and hydrological extremes in the 21 st century. The uncertainty of results for all basins is high. Still, climate change impact is clearly visible for mean discharges but also for extremes in high and low flows. The uncertainty of the projections is the lowest in the Upper Blue Nile, where an increase in streamflow is most likely. In the Niger and the Limpopo basins, the magnitude of trends in both directions is high and has a wide range of uncertainty. In the Oubangui, impacts are the least significant. Our results confirm partly the findings of previous continental impact analyses for Africa. However, contradictory to these studies we find a tendency for increased streamflows in three of the four basins (not for the Oubangui). Guided by these results, we argue for attention to the possible risks of increasing high flows in the face of the dominant water scarcity in Africa. In conclusion,
\end{abstract}

the study shows that impact intercomparisons have added value to the adaptation discussion and may be used for setting up adaptation plans in the context of a holistic approach.

\section{Introduction}

Climate change impacts are commonly assessed on two different scales: the global or continental scale allows for a general view of the larger context and patterns, whereas regional studies focus on details, for example flood or drought hazards. By comparing climate change impacts between different regions, advantages of both approaches can be combined. This way of bridging these two scales is likely to give new insights into the characteristics of climate change in the actual regions, but also beyond.

Especially on the African context, this approach could be beneficial where climate change impacts are very likely to be most severe (Boko et al., 2007), and adaptation measures will increasingly stand in competition for finance and precedence (NWP, 2011). Here, regional intercomparison of climate impacts could be beneficial not only scientifically but also for developing regional adaptation strategies.

On the continental level, there have been several climate impact studies focusing on water resources in Africa. In a recent study, Faramarzi et al. (2013) modelled the whole African continent with the SWAT (Soil and Water Assessment Tool) model on a coarse spatial resolution (1496 subbasins), using five CMIP4 (Coupled Model Intercomparison Project Phase 4) global circulation models (GCM: HadCM3, PCM, CGCM2, CSIRO2, ECHAM4). They compared their 
results to the available literature sources on future projections of streamflow in Africa, namely De Wit and Stankiewicz (2006) and Strzepek and McCluskey (2007), and several projections for smaller regions. They generally found similar trends in the studies, with decreases in the Sahel region and southern Africa between 10 and $20 \%$ and an increase in central and eastern Africa between 10 and $20 \%$, but with significant spatial variability. De Wit and Stankiewicz (2006) defined three different regimes according to a precipitation threshold for the African continent and calculated for these three regimes the perennial drainage density as a function of mean annual rainfall. By using six GCMs (not specified) to assess the projected changes in mean annual rainfall across Africa, they found that $25 \%$ of the continent will be significantly affected by a decrease in streamflow by the end of this century. Strzepek and McCluskey (2007) simulated changes in streamflow and soil moisture with a conceptual rainfall-runoff model called WatBal. It was applied on grids for five CMIP4 models (CSIRO2, HadCM3, CGCM2, ECHAM, PCM) and the scenarios A2 and B2 across the African continent, and results were provided by country. A study of Mahe et al. (2013) analyzed observed streamflow of the past decades in west and central Africa and found a modification of seasonal regimes in the Equatorial area and a decrease in the groundwater table in the tropical humid area of west Africa.

However, no impact studies currently exist that investigate projected change in hydrological extremes on a regional resolution consistently across the African continent, that could for the first time enable an intercomparison of the future severity of change and consequently allow an assessment of the urgency of required adaptations. In this modelling study, we attempt to overcome this apparent lack by quantifying the impact of climate change on the mean river discharge as well as extremes for four major African basins that cover the main sub-Saharan climate zones: the Niger, the Upper Blue Nile, the Oubangui (Upper Congo basin) and the Limpopo. For these basins, we focus on water as the key resource for development and flood security as well as economic development and livelihood. Moreover, we applied the most upto-date knowledge (the model outputs from CMIP5 for the representative concentration pathways, RCPs, Van Vuuren et al., 2011a) to investigate climate impacts in Africa. Therefore, the objectives of the study are (1) to investigate differences in the sensitivity of modelled annual discharge to climate parameters between the basins, (2) to study climate impacts on river discharge for four basins in terms of quantity and seasonality, (3) to explore changes in hydrological extremes (high flow, low flow) for the four basins, (4) to analyze the uncertainties of the projections, and finally (5) to identify and discuss the implications for adaptation.

To achieve these objectives, we analyze the output of 19 CMIP5 model with regard to temperature and precipitation trends. Then, data for five of these climate models which have been bias corrected by the method of Hempel

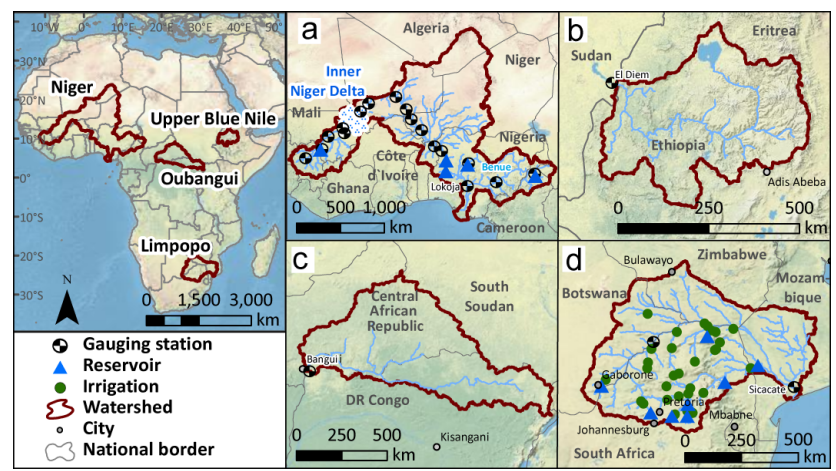

Fig. 1. Map of the four modelled basins: Niger (a), Upper Blue Nile (b), Oubangui (c), Limpopo (d).

et al. (2013) are used to drive the eco-hydrological model SWIM (Soil and Water Integrated Model, Krysanova et al., 1998) for each basin. In the main part of this study, we compare projections of future discharge trends for mean discharges as well as for robust indicators of extremes considering $30 \mathrm{yr}$ periods in the first and second halves of the $21 \mathrm{st}$ century under the RCPs 2.6 and 8.5. These quantitative results are interpreted and compared across the four case studies qualitatively. In a final discussion, we evaluate the potential of such an impact comparison to contribute to developing an agenda for climate change adaptation.

\section{Study sites}

\subsection{Hydrology of the basins}

The selected basins of the Niger, Upper Blue Nile, Oubangui and Limpopo are distributed over all sub-Saharan Africa, in the west, east centre and south (Fig. 1). In addition they cover all climate groups of sub-Saharan Africa according to the Köppen (1900) classification after Strahler (2013). Besides the tropical humid climates (A), dry climates (B), subtropical climates $(\mathrm{C})$ and highland climates $(\mathrm{H})$ they also cover most of the climatic types and subtypes of the continent.

The hydrological regimes of all four rivers are characterized by the alternation of dry and wet seasons. However, the diverse climates, topographical and geological conditions, soils, and vegetation types result in characteristic hydrological conditions in each of the basins. This can exemplarily be seen in the broad spectrum of runoff coefficients in the catchments, ranging from about $2 \%$ in the Limpopo catchment to $21 \%$ in the Oubangui (Fig. 1 and Table 1).

The Niger River is the longest and largest river of west Africa. Its source is located in the Guinean highlands, from which the Niger flows in a northern arc through the dry Sahelian zone until it again enters the wetter tropical region north of the Gulf of Guinea. Topographically the basin also includes Algeria, but from this northernmost part in the central Sahara, no water contributes to the streamflow. 
Table 1. Basin and river characteristics.

\begin{tabular}{|c|c|c|c|c|}
\hline & Niger & Upper Blue Nile & Oubangui & Limpopo \\
\hline Area in $\mathrm{km}^{2}$ & 2156000 & 167000 & 489000 & 413000 \\
\hline Alt. range in $\mathrm{m}$ a.s.l. & 0-2961 & $526-4187$ & $341-2046$ & $0-2326$ \\
\hline Mean temp. in ${ }^{\circ} \mathrm{C}$ & 28 & 19 & 25 & 21 \\
\hline Mean temp. warmest/ & 32 in May/ & 21 in Apr./ & 26 in Mar./ & 25 in Feb./ \\
\hline coldest month in ${ }^{\circ} \mathrm{C}$ & 24 in Jan. & 17 in Dec. & 24 in Dec. & 15 in Jul. \\
\hline Mean prec. in $\mathrm{mm} \mathrm{a}^{-1}$ & 682 & 1382 & 1507 & 530 \\
\hline \multirow{3}{*}{ Dominant land uses in \% } & cropland: 20 & & forest: 34 & \\
\hline & grassland: 18 & cropland: 57 & forest: 50 & cropland: 32 \\
\hline & savannah 14 & savannah: 30 & cropland: 32 & savannah: 20 \\
\hline Length of river in $\mathrm{km}^{*}$ & $\sim 3650$ & $\sim 800$ & $\sim 1670$ & $\sim 1750$ \\
\hline Mean annual discharge in $\mathrm{mm} \mathrm{a}^{-1}$ & $\sim 170$ & $\sim 370$ & $\sim 224$ & $\sim 13$ \\
\hline Runoff coefficient $* *$ & $\sim 18 \%$ & $\sim 17 \%$ & $\sim 21 \%$ & $\sim 2 \%$ \\
\hline
\end{tabular}

* Until the relevant gauging stations. Niger: Lokoja; Upper Blue Nile: El Diem; Oubangui: Bangui; Limpopo: Sicacate.

** Amount of precipitation that reaches the outlet.

Geographically, the Niger basin spreads over six different large agro-climatic and hydrographic regions. These range from the central Sahara with less than $100 \mathrm{~mm} \mathrm{yr}^{-1}$ average annual rainfall to tropical rain forests in the Guinean zone with more than $1400 \mathrm{~mm} \mathrm{yr}^{-1}$. Besides this broad range of climates, the regime of the Niger is substantially influenced by the Inner Niger Delta by delaying the peak runoff and smoothening the hydrograph. The fluvial regime at the analyzed Lokoja gauge is mainly shaped by the wetter climate of upstream parts of the basin and the Niger tributaries, particularly the Benue. However, the influence of the dynamics of the Inner Niger Delta and the Guinean headwaters is still noticeable (Andersen, 2005; Ogilvie et al., 2010).

The Oubangui River is a main tributary of the Congo River in the north-east of the basin. The source of the Oubangui is located in the mountains near Lake Albert. From the Bangui gauging station the Oubangui still flows $600 \mathrm{~km}$ further until it reaches the Congo River. Its regime follows the rainy season, with highest discharges from August to December and a total annual rainfall between 1300 and $1700 \mathrm{~mm} \mathrm{yr}^{-1}$. The basin is dominated by a vast peneplain and only $5 \%$ of its area is covered with mountains, mainly at the eastern and northeastern edges. The Oubangui basin is the least investigated of all four African basins and data is - even for African conditions - sparse (Tshimanga, 2012; Tshimanga and Hughes, 2012; Shanin, 2002; Wesselink et al., 1996).

The Upper Blue Nile is the Ethiopian segment of the Blue Nile. After the White Nile, the Blue Nile is the second longest tributary to the Nile River. It contributes up to $80 \%$ of the mean annual discharge to the stem Nile. The source of the Blue Nile is Lake Tana and its tributaries. From Lake Tana, the Blue Nile flows across northwestern Ethiopia through numerous incised valleys and canyons and crosses the border to Sudan at El Diem. The major influences on the hydrological regime of the catchment are a distinct topography and a wide range of climatic conditions. The altitude within the basin ranges from $4050 \mathrm{~m}$ a.s.l. in the Ethiopian highlands to $500 \mathrm{~m}$ a.s.l. at the outlet at El Diem. Besides the influence of this landform, the effects of the summer monsoon determine the climate in the basin. Annual rainfall ranges from 1077 to over $2000 \mathrm{~mm} \mathrm{yr}^{-1}$ in the highlands (Conway, 2000).

The Limpopo River originates in Witwatersrand, South Africa, from which it flows in a northern arc and then enters the Indian Ocean. The hydrology of the Limpopo is characterized by its location in the transition zone between the intertropical convergence zone and the tropical dry zone, with additional maritime influence in the east. Its topography is dominated by plains of higher altitude in the inland and lower coastal plains, both separated by the Great Escarpment, which runs through the centre of the basin from north to south. This geographical setting results not only in a typical subtropical intra-annual, but also a very distinct interannual variability of flow (UN-HABITAT, 2007; Frenken and Faurès, 1997; FAO, 2004).

\subsection{Human influence on discharge dynamics in the basins}

The intensity of human influence on the hydrological processes differs remarkably in the four basins. The Limpopo River basin is located in an arid to semi-arid region where water is the critical limiting factor on all development. Water resources including groundwater are heavily utilized due to the densely populated area and many irrigation schemes (UN-HABITAT, 2007). In order to satisfy the intensive use of water resources, the Limpopo River is quite developed in terms of storage reservoirs and dams. In the South African part of the Limpopo basin alone, there are 160 dams classified as large dams in accordance with the criteria of the International Committee on Large Dams. Among these 160 dams, 15 of them have storage capacities above $100 \mathrm{Mm}^{3}$, and 34 
are between 10 and $100 \mathrm{Mm}^{3}$ (LBPTC, 2010). In addition, there is a lot of mining activity in the Limpopo River basin with about 1900 mines over the years (Ashton et al., 2001b), and many of them have extensive impacts on water resources (Ashton et al., 2001a).

In the Niger, water management infrastructure does not influence the streamflow fundamentally on the basin scale. Currently there are only five major reservoirs in the catchment with volumes over $1000 \mathrm{Mm}^{3}$, mainly built for irrigation and hydropower: Selingué (Mali), Kainji, Jebba, Shiroro (all three in Nigeria) and Lagdo (Cameroon). These influence the streamflow locally and are included in the model. The Niger is navigable from Koulikoro in central Mali to Lokoja in Nigeria, mainly in the season of highest discharge from October to January (Andersen, 2005).

In the Upper Blue Nile basin, water management still plays a moderate role. At the end of the 1990s, the irrigation potential was estimated by the FAO to be more than $2.2 \mathrm{Mha}$ (Frenken and Faurès, 1997). Since then, efforts to exploit this potential have been moderate. However, over the last decade many efforts have been made for intensification of irrigated agriculture and other management measures, of which the Grand Ethiopian Renaissance Dam is the most prominent. After planned completion in 2017, the dam should store a water volume of $63000 \mathrm{Mm}^{3}$ and will serve power generation of $5000 \mathrm{MW}$ (Salman, 2013). The Upper Blue Nile is not navigable for larger boats (Awulachew et al., 2007).

In the Oubangui basin, information and data on water management is very sparse. There are three reservoirs in the headwater part that generate hydropower. The river serves as a major traffic route for the Central African Republic, though there are reports of insufficient streamflow for navigation over an increasing period throughout the year (UN, 2009). Consumption and small-scale irrigation along the river play a minor role and the influence on the discharge and hydrological regime is small (Vanden Bossche and Bernacsek, 1990).

\section{Methodology}

\subsection{Model}

All four African basins were modelled using the ecohydrological model SWIM (Krysanova et al., 1998). The model was chosen because it is able to reproduce discharge on the mesoscale on a daily basis with high efficiency and has been used extensively in many catchments of various sizes all over the world, including in Africa (Liersch et al., 2013; Koch et al., 2013). This semi-distributed model is based on the models SWAT (Arnold et al., 1993) and MATSALU (Krysanova et al., 1989). SWIM is a process-based model and simulates the dominant eco-hydrological processes such as evapotranspiration, vegetation growth, runoff generation and river discharge, and also considers feedbacks among these processes (Krysanova et al., 2005) (Fig. 2). The

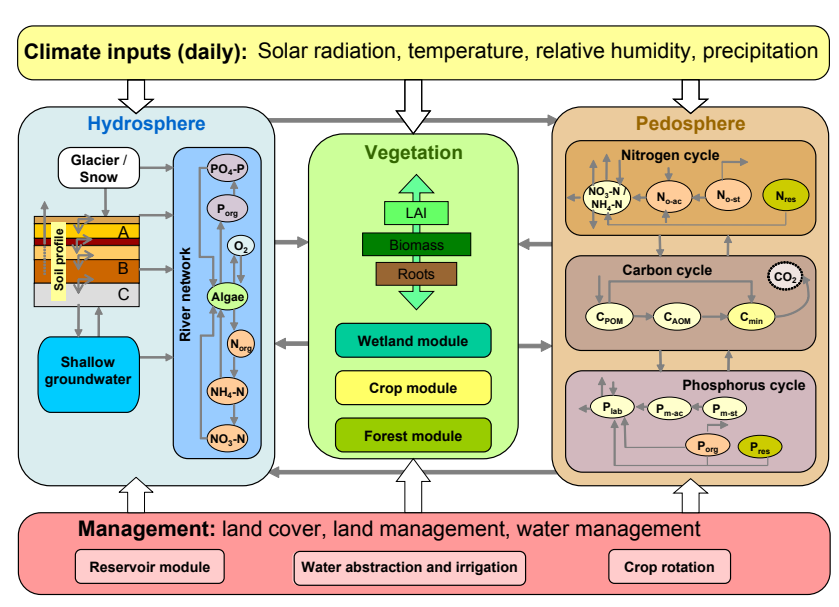

Fig. 2. Structure of the eco-hydrological model SWIM.

model is described in detail in Krysanova et al. (2000) and Krysanova et al. (2005). Recent model developments and extensions that are used in the different basin model projects for this study are described in Sect. 3.3.

SWIM disaggregates a river basin to subbasins and hydrotopes. The subbasins were delineated on the basis of flow accumulation in a digital elevation model (DEM). The size of the subbasins usually ranges between $150-1500 \mathrm{~km}^{3}$, depending on topography and the focused precision. In large basins as modelled in this study, the size of the subbasins derived in the delineation process is a trade between the exactness of the model and its manageability. The resulting subbasins are then subdivided into hydrotopes, each with same type of soils and land use class. The daily weather input is interpolated to subbasin centroids, and includes mean, minimum and maximum temperature, as well as precipitation, relative humidity and global radiation.

On each hydrotope within a subbasin the daily weather is added. Subsequently in each of these hydrotopes, the model is calculating water fluxes and the water balance for the soil column subdivided into several layers. Its hydrological system includes the soil surface, the root zone of the soil and the shallow aquifer. The output of each hydrotope is then aggregated at subbasins level, taking retention into account, and then the routing of lateral fluxes starts. The basin can be subdivided into subcatchments which can be separately parameterized if discharge data is available for the outlet of each subcatchment.

For each African basin, the model has been individually adapted and calibrated with regard to its geographical and bio-physical settings (see Sect. 3.3).

\subsection{Data}

For all four regions, a digital elevation model derived from the Shuttle Radar Topography Missions with $90 \mathrm{~m}$ resolution (Jarvis et al., 2008). Soil parameters were derived from 
the Digital Soil Map of the World (FAO et al., 2012). Relevant soil data for SWIM includes its depth, clay, silt and sand content, bulk density, porosity, available water capacity, field capacity, and saturated conductivity for each of the soil layers. Land use data were reclassified from the global land cover (Bartholomé and Belward, 2005). Land use classes of SWIM include water, settlement, industry, road, cropland, meadow, pasture, mixed forest, evergreen forest, deciduous forest, wetland, savannah (heather) and bare soil.

Climatic observations are generally sparse in Africa and very inhomogeneously distributed over the continent. Therefore, and for better comparability of the results, we calibrated the model for four basins using a reanalysis climate data set produced within the EU FP6 WATCH project (WFD, 2011; Weedon et al., 2011). This data contains all variables required for SWIM on a daily basis on a $0.5^{\circ} \times 0.5^{\circ}$ grid. Observed river discharge data from the Global Runoff Data Centre was used to calibrate and validate the model (Fekete et al., 1999).

For analyzing climate trends, we used the output of an ensemble of 19 CMIP5 ESMs. Of this ensemble, five ESMs (HadGEM2-ES, IPSL-5 CM5A-LR, MIROC-ESM-CHEM, GFDL-ESM2M, NorESM1-M) outputs were used for driving the hydrological model (Table 2). The accurate way of choosing the ESMs for the regions would have been a skill test (see IPCC-TGICA, 2007; Tshimanga and Hughes, 2012). But as we compare different regions and have to maintain the same ESMs for the intercomparison we used all five models which are available in a bias corrected version (Hempel et al., 2013), taking into account that the relative performance of the ESMs in reproducing historical patterns will be ignored. Instead we added an analysis where we compare the chosen ESMs with the whole ensemble in order to see their characteristics in terms of precipitation and temperature (Figs. 5 and 6).

The five chosen ESMs have been downscaled using a trend-preserving bias correction method with the WFD reanalysis data, and have been resampled on a $0.5 \times 0.5$ grid for the time period 1950-2099 (Hempel et al., 2013). "Representative concentration pathways" (RCP) cover different emission concentrations, and in this study the RCP 2.6 and 8.5 scenarios were used for all 5 ESMs to cover the low and high ends of possible future climatic projections. The RCP 2.6 corresponds likely to a warming of less than $2{ }^{\circ} \mathrm{C}$ increase of global temperature above the pre-industrial level until the end of the century (Van Vuuren et al., 2011b), and the RCP 8.5 to a likely increase of $3.8-5.7^{\circ} \mathrm{C}$ (Rogelj et al., 2012). The trend preservation in the bias correction can lead to extreme precipitation corrections in exceptional cases. An example of this can be seen in the case of the IPSL model in the Upper Blue Nile basin, where the almost rainless October was corrected by a high factor during the base period. In the future scenarios, this factor resulted in a very strong increase in precipitation during October, which exceeds the usual peak of the rainy season in August (see Fig. S2 in the Supplement).

\subsection{Model set-up and calibration}

Table 3 summarizes the basic model set-up and calibration information as well as the results of the validation. The Niger basin is geographically the most heterogeneous of the four basins and covers the largest area (Table 1). Therefore, the availability of a sufficient number of discharge gauging stations to cover the heterogeneity of the basins was crucial for the set-up of the model. The 1923 subbasins were integrated to form 18 subcatchments, each associated with a gauge at its outlet. These subcatchments were calibrated individually in order to adapt the model as closely as possible to the regional conditions (Table S1 in the Supplement).

In addition to this heterogeneity the flood plains of the Inner Niger Delta (IND) in Mali have a significant impact on the flow regime of the Niger River. About $40 \%$ percent of the inflowing water evaporates from the huge floodplain and discharge patterns at the outlet differ significantly. It is therefore indispensable to incorporate processes such as flooding and release into the hydrological model in order to account for increased infiltration and evaporation from the additional water surface. Based on the digital elevation model, inundation zones are delineated for each subbasin in the floodplain. Moreover, ponds were identified where water gets trapped and is not allowed to flow back to the channel system. It is assumed that if discharge exceeds the water holding capacity of the river at a subbasin inlet, the surplus flows into the inundation zone(s). This threshold is computed by multiplying cross-sectional area by flow velocity. At each time step, water is released from the storages into the downstream subbasin according to the routing scheme. The volume of water to be released from storage is a linear function of the current storage volume. Areas (hydrotopes) in the flood plain switch dynamically from water to land phase implementing different functions for land cover, infiltration, percolation and evapotranspiration. The SWIM inundation module which is described in detail in Liersch et al. (2013) significantly improved discharge simulations at the IND outlet. The five largest reservoirs were included in the model setup (see Sect. 2.2). A reservoir module developed by Koch et al. (2013) was used for this purpose.

The calibration of the model for the Upper Blue Nile basin was limited to one gauging station, namely El Diem at the Sudanese-Ethiopian border. For this basin, the quality of radiation data within the WFD data set was insufficient when compared with the World Radiation Data Center (WRDC, 2000) data. Radiation was underestimated, especially during the rainy season. Therefore, global radiation was estimated for this basin by means of the latitude as well as minimal and maximal daily temperatures, using the method of Hargreaves and Samani (1982). Further, the vegetation module was adapted to spatially varying temperature conditions in the topographically very heterogeneous catchment to provide more realistic regional vegetation growth. Water management was not implemented in the model of this 
Table 2. Earth system models driving the SWIM model.

\begin{tabular}{|c|c|}
\hline Model name & Institution \\
\hline HadGEM2-ES & $\begin{array}{r}\text { Met Office Hadley Centre Earth } \\
\text { System Modelling group, England }\end{array}$ \\
\hline IPSL-5 CM5A-LR & Institut Pierre-Simon Laplace, France \\
\hline MIROC-ESM-CHEM & $\begin{array}{r}\text { Japan Agency for Marine-Earth Science and Technology, } \\
\text { Atmosphere and Ocean Research Institute, Japan }\end{array}$ \\
\hline GFDL-ESM2M & $\begin{array}{r}\text { Geophysical Fluid Dynamics Laboratory of the National } \\
\text { Oceanic and Atmospheric Administration, USA }\end{array}$ \\
\hline NorESM1-M & Norwegian Climate Centre, Norway \\
\hline
\end{tabular}

Table 3. Characteristics of basin models and validation results.

\begin{tabular}{|c|c|c|c|c|}
\hline & Niger & Upper Blue Nile & Oubangui & Limpopo \\
\hline Number of subbasins & 1923 & 558 & 377 & 2020 \\
\hline Number of hydrotopes & 13883 & 1700 & 1734 & 13085 \\
\hline Number of included reservoirs & 5 & 0 & 0 & 8 \\
\hline Number of included irrigation schemes & 0 & 0 & 0 & 31 \\
\hline Number of gauging stations used for calibration & 18 & 1 & 1 & 2 \\
\hline Gauging station(s) used for calibration/validation & Lokoja $^{\mathrm{a}}$ & El Diem & Bangui & Sicacate, Oxenham Ranch \\
\hline Calibration period & $1972-1982^{\mathrm{a}}$ & $1961-1970$ & $1981-1990$ & $1971-1978$ \\
\hline $\mathrm{NSE}^{\mathrm{b}}$ (daily) & 0.92 & 0.81 & 0.66 & $0.72,0.73$ \\
\hline PBIAS $^{\mathrm{c}}$ & 8.6 & 20.9 & 19.1 & $11.5,-6.7$ \\
\hline Validation period & $1983-1992^{\mathrm{a}}$ & $1971-1980$ & $1971-1980$ & $1980-1987^{\mathrm{d}}$ \\
\hline $\mathrm{NSE}^{\mathrm{b}}$ (daily) & 0.89 & 0.63 & 0.6 & 0.55 \\
\hline $\mathrm{NSE}^{\mathrm{b}}$ (monthly) & 0.9 & 0.73 & 0.63 & 0.8 \\
\hline PBIAS $^{\mathrm{c}}$ & 2.1 & 39 & 15.7 & 3.4 \\
\hline
\end{tabular}

${ }^{a}$ In the Niger basin 18 gauging stations have been used for the calibration. For the additional 17 calibration periods and results see Table S1 in the Supplement. ${ }^{b}$ Nash-Sutcliffe efficiency. ${ }^{c}$ Percent bias of monthly average. ${ }^{\mathrm{d}}$ The gauging station Oxenham Ranch was only used for calibration and not validated.

basin because the influence of streamflow management is still negligible.

The Oubangui basin consists mainly of a peneplain and contains a broad range of different soil and vegetation types. The model for the catchment was calibrated for the gauging station Bangui. Precipitation data for the Oubangui basin in the WFD are based on very sparse climate observation data from the Global Precipitation Climatology Centre's precipitation data (GPCC). The interpolation and correction method for precipitation of WFD thus produced unrealistically high precipitation values for the Oubangui. Therefore, WFD precipitation was replaced by original uncorrected GPCC data for the calibration in this basin while all other parameters are still from the original WFD (Schneider et al., 2014). Another particularity of the Oubangui basin is the almost complete cover by tropical evergreen forest. As the SWIM vegetation module has not yet been adapted to this type of vegetation, it was not been simulated in the Oubangui catchment. Instead, leaf area index and rooting depth were used as additional calibration parameters. Due to the sparse data, the reservoirs of the Oubangui basin could not be included in the model.
The SWIM model was calibrated for the Limpopo basin using discharge data from the Sicacate gauging station in South Africa and the Botswanan station Oxenham Ranch. However, the main challenge for the modelling of this basin was a strong effect of human intervention on the river discharge. Therefore, the largest eight reservoirs were included in the model with the input data on reservoir capacity and withdrawal amount from the reservoirs. In addition, 31 intensive irrigation sites with an annual abstraction rate over $6.3 \mathrm{Mm}^{3}$ were identified and included in the model. Taking into account the annual abstraction rate, the monthly share of irrigation and the estimated return flow after irrigation, the daily irrigation demand was calculated for each irrigation site. The irrigation module of SWIM abstracts the irrigation demand from the specific river reaches as long as the amount of irrigation water is available in the river. 


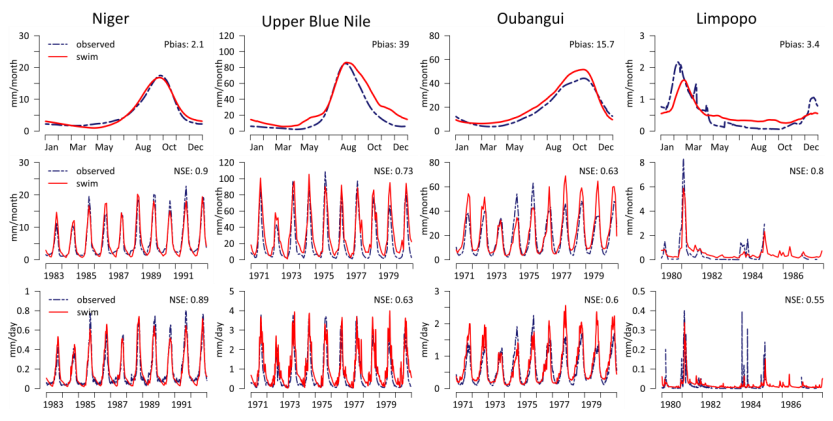

Fig. 3. Validation of SWIM at the outlets of the four basins. In the top row the seasonality of monthly runoff rate in validation period and PBIAS, in the middle row the monthly runoff rate and in the bottom row the daily runoff rate in the validation period, both with Nash-Sutcliffe efficiency.

\section{Results}

\subsection{Validation of the model}

The SWIM model was validated for the gauging stations at the outlets of the four basins; the results are presented in Fig. 3. To quantify the efficiency of the model we applied the method of Nash and Sutcliffe (1970) (NSE), and percent bias (PBIAS) was used for evaluation of model error. The validation period was chosen independently from the calibration period and lasted at least eight years (Table 3). The focus of the calibration and model set-up for all four basins was to achieve adequate efficiency for streamflow simulations for daily time steps, for mean as well as high and low flows. The high flows refer in this context for discharge peaks during the rainy season and low flows as the minimum discharge during the dry season, and are quantified as $Q_{10}$ and $Q_{90}$, correspondingly.

The SWIM model was basically able to reproduce the hydrological characteristics of each basin reasonably well, with NSE of the monthly runoff rate ranging between 0.63 and 0.9 and the daily runoff rate ranging from 0.55 to 0.89 . However, the validation showed heterogeneous results in terms of the NSE, ranging from adequate in the Oubangui basin and Limpopo basin to very good in the Niger basin. The model was able to reproduce high and low flows for the Niger basin well, and in terms of seasonality the results are very good for both daily and aggregated monthly model output. The Upper Blue Nile basin shows good results for the modelling of seasonality for daily and monthly output data with adequate representation of high flows but an overestimation during the low flow. For the Limpopo basin the difference between daily and monthly runoff rate is high. When aggregated to monthly time series, the validation shows a slight underestimation of high flow and overestimation of low flow, but the total efficiency is good. For the daily time series, some peaks were well modelled but others are missing almost completely. The model for the Oubangui basin has distinct deficiencies in re-
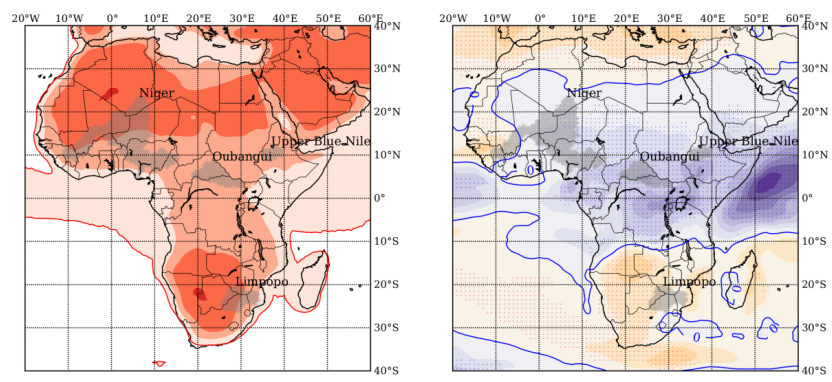

- $80 \%$ agreement in TREND direction
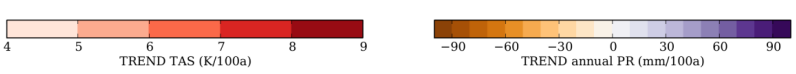

Fig. 4. Mean temperature (left) and precipitation (right) trends over the African continent for 19 CMIP5 models from 2006-2100 for RCP 8.5. For precipitation, an agreement in trend direction of $80 \%$ or more of the models is marked with a dot.

producing high and low flows, but regarding discharge seasonality the model gives adequate results during the validation period for monthly and daily data.

\subsection{Climate trends}

Precipitation and temperature are the key drivers for the hydrological regime of rivers, and climate change has its main impact through changes in these two variables. In Fig. 4, we show the mean trends for these two parameters from 2006 until 2100 projected by 19 CMIP5 models for the whole African continent. Shown are the results for RCP 8.5 in order to illustrate the most pronounced trends under extreme scenario conditions.

All models agree on a distinct temperature rise over the whole African continent, while in the tropics much of the additional energy input is converted to latent heat. The highest increase of 6 to $7^{\circ} \mathrm{C}$, in some parts even up to $8^{\circ} \mathrm{C}$, is projected over the already driest and hottest areas in the Sahara and southern African savannahs and deserts. The catchments of the Niger and Limpopo are partly located in these zones of the most extreme temperature increases. The Upper Blue Nile and Oubangui basins are located in regions with a lower but still very distinct warming trend. Here, temperatures rise between 4 and $6{ }^{\circ} \mathrm{C}$, whereas the coastal zones generally show a lower rise in temperature.

For precipitation, the model agreement is considerably lower. The Niger basin can be divided into an area with a negative precipitation trend in the headwaters of the river in the west, and a positive trend in the eastern part. The longitudinal trend intensifies eastwards, and in the headwaters of the Benue tributary in Cameroon most models agree on a distinct precipitation increase. The Upper Blue Nile and the Oubangui are located in the inner tropical belt, where at least $80 \%$ of the models agree on the positive precipitation trends. The precipitation trend for the Limpopo basin is negative, with a 

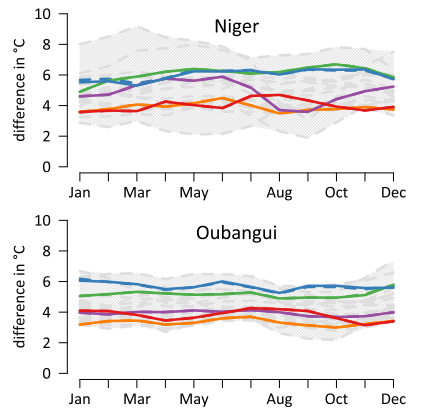

- GFDL - Hadley — IPSL - MIROC - Nor
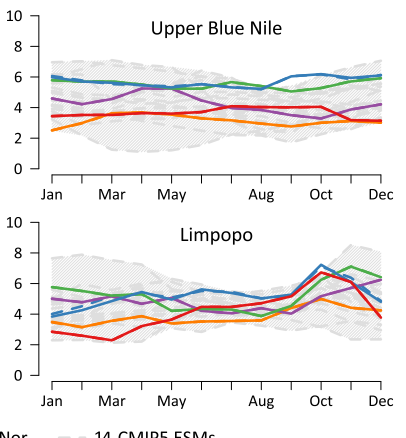

Fig. 5. Difference in monthly mean temperature in the far projection period (2070-2099) relative to the base period (1970-1999) for RCP 8.5 for five bias corrected model projections (coloured lines), the uncorrected ESMs (coloured dashed lines) and 14 ENSEMBLE ESMs (grey dashed lines).

high agreement in the western part of the basin, where most of the rain falls. Here major changes seem most probable.

For the projection of streamflow, we use the bias corrected model output of 5 ESMs (HadGEM2-ES, IPSL-5 CM5ALR, MIROC-ESM-CHEM, GFDL-ESM2M, NorESM1-M). In Figs. 5 and 6, temperature and precipitation of these climate runs were compared to the uncorrected runs and 14 other CMIP5 models in order to display the influence of the bias correction and where the respective models lie in a larger ensemble (i.e. if the model is especially dry or wet, warm or cold or in the middle of the whole ensemble). In Fig. 5, the seasonal changes between mean monthly temperatures show a distinctly homogeneous pattern. In all four basins, the temperature rises between $\sim 3$ and $\sim 6^{\circ} \mathrm{C}$. In the basins of the Niger, Oubangui and Upper Blue Nile, all 5 models chosen project a homogeneous increase throughout the year; Hadley and IPSL outputs are the most extreme with increases between 5 and $6^{\circ} \mathrm{C}$, GFDL and Nor project a moderate increase of less than $4^{\circ} \mathrm{C}$, and MIROC results are in the middle with the highest variance. In the Limpopo basin, all models agree on the range of warming between 2.5 and $6.5^{\circ} \mathrm{C}$, and on the same pattern of warming, most pronounced from August to December. Hadley and GFDL again show the highest mean annual warming, and GFDL reaches the same level of warming during the first half of the rainy season from August to December. The bias correction hardly influenced the temperature. The five selected model outputs cover the temperature range of the CMIP5 ensemble in all four basins well.

In Fig. 6, we compare monthly precipitation in the same periods for the RCP 8.5. For the Niger, the range of uncertainty for the five models chosen is very high. It ranges from $\sim 150 \mathrm{~mm} \mathrm{month}^{-1}$ increase during the rainy season (MIROC model) to $25 \mathrm{~mm} \mathrm{month}^{-1}$ decrease (GFDL model), which means a range between $\sim 120 \%$ and minus $\sim-20 \%$. Compared with the uncorrected model runs, the MIROC model unexpectedly shows a distinct increase in
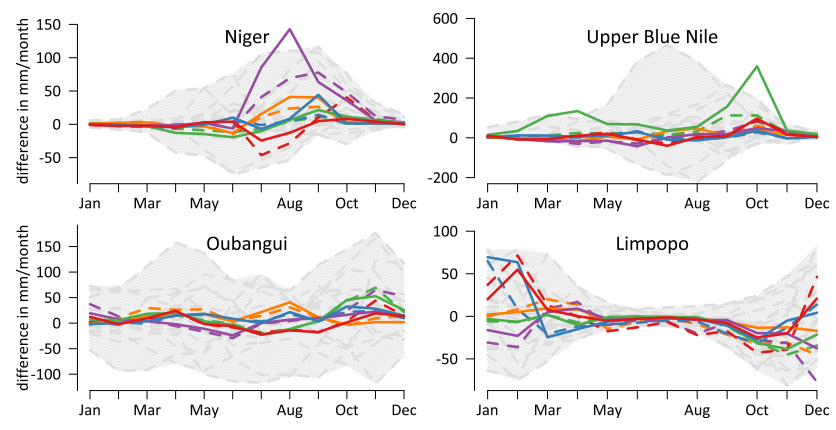

— GFDL - Hadley - IPSL - MIROC - Nor - 14 CMIP5 ESMs

Fig. 6. Difference in monthly precipitation in the far projection period (2070-2099) relative to the base period (1970-1999) for RCP 8.5 for five bias corrected model projections (coloured lines), the uncorrected ESMs (coloured dashed lines) and 14 ENSEMBLE ESMs (grey dashed lines).

trend, caused by the correction (see discussion in Sect. 5.4). For the other models, the correction slightly decreases the means of the monthly trend. During the dry season from November to March, there is no visible trend in precipitation. The selection of five models represents the precipitation range of the CMIP5 ensemble well for the Niger basin though there are deficits between March and June.

The five bias corrected models for the Upper Blue Nile basin all agree on an increasing trend in precipitation. The increase in the IPSL model of almost $400 \mathrm{~mm}$ month $^{-1}$ $(\sim 100 \%)$ at the end of the rainy season is striking. All other bias corrected models show a slight increase in precipitation of less than $40 \mathrm{~mm} / \mathrm{month}$ during the rainy season, which corresponds to less than $20 \%$. The difference from the uncorrected model runs is minor in this basin, except for the IPSL run which again unexpectedly shows a distinct increase in trend as a result of the correction (see discussion in Sect. 5.2). During the dry season from December to May, there is no trend in precipitation (except IPSL). In this basin, selection of the five corrected climate runs diminishes the range of the whole CMIP5 ensemble particularly from June to September, which should be taken into account when interpreting the results.

In the Oubangui catchment, the trends of the five CMIP5 models chosen are rather minor. All models agree on an increasing precipitation trend from $\sim 20$ to $\sim 50 \mathrm{~mm} \mathrm{month}^{-1}$, which is less than $20 \%$ with no obvious pattern. The effects of the bias corrections are minor for all five models. As the dry season is not significant in this region and lasts not longer than two months, the precipitation trends are distinct throughout the entire year. The selection of the five corrected climate runs results in a substantially reduced range of the whole CMIP5 ensemble, which also reduces the informative value for the discussion.

Precipitation trends for the five models chosen in the Limpopo basin all agree on a decrease at the beginning of the 

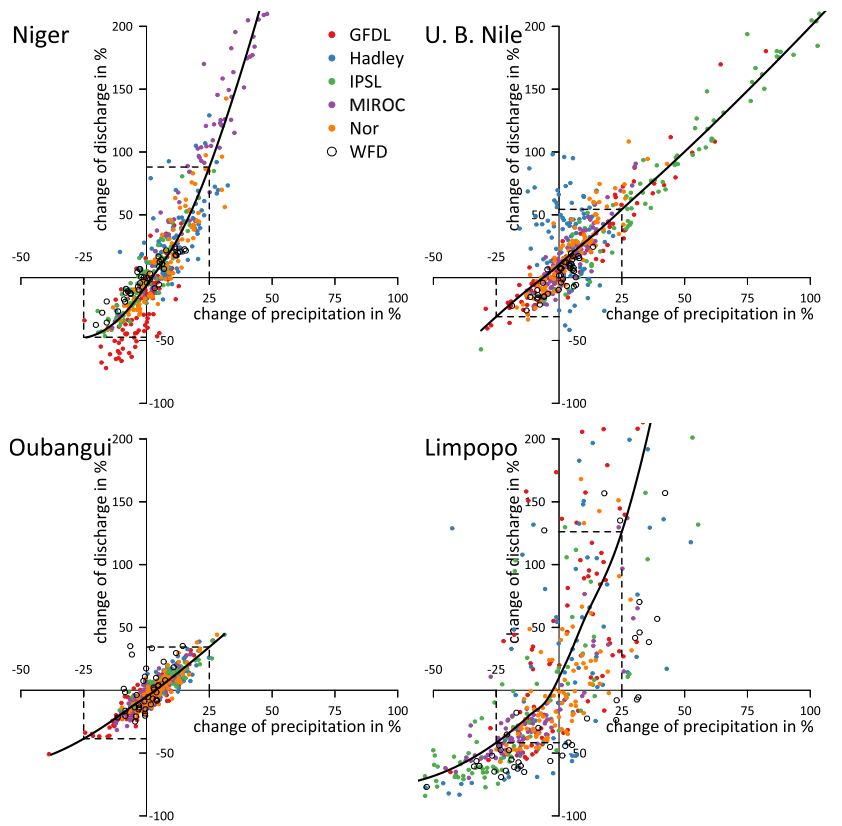

Fig. 7. Climate sensitivity in the four basins. Change in modelled annual discharge [percent] per change of precipitation [percent] for 2006-2099 compared to the mean of base period 1970-1999 for five climate models in RCP 8.5 and WFD. Curve shows fitted local regression over all values.

rainy season in October. During the main rainy season from December to March, Hadley and GFDL show an increase of over $50 \mathrm{~mm} \mathrm{month}^{-1}$, which corresponds to an increase of over $50 \%$. The other three models show minor decreases or no trend at all. The correction of the models with the ISIMIP method results in less distinct trends for increases as well as for decreases (see discussion in Sect. 5.2). In the Limpopo basin, the dry season lasts from May to November and during this period there are no trends in precipitation. The selection of five models of the CMIP5 ensemble covers the whole range of precipitation trends in the Limpopo basin with deficits from August to November.

\subsection{Climate sensitivity}

Figure 7 illustrates the sensitivity of river discharge to climate variability and change in the four basins. Shown is the change in percentage for the total precipitation over 12 months beginning with the driest month, against the total discharge during the related hydrological year. As base values for all five selected climate models runs of RCP 8.5 serve the means of the base period (1970-1999). The anomalies are then plotted for each year from 2006 until 2099. Additionally, we show the anomalies for the runs with the reanalysis WFD climate input from 1960-2001. Changes in precipitation are shown in the range from -50 to $100 \%$, and for discharge from -100 to $200 \%$. Values outside this range are not

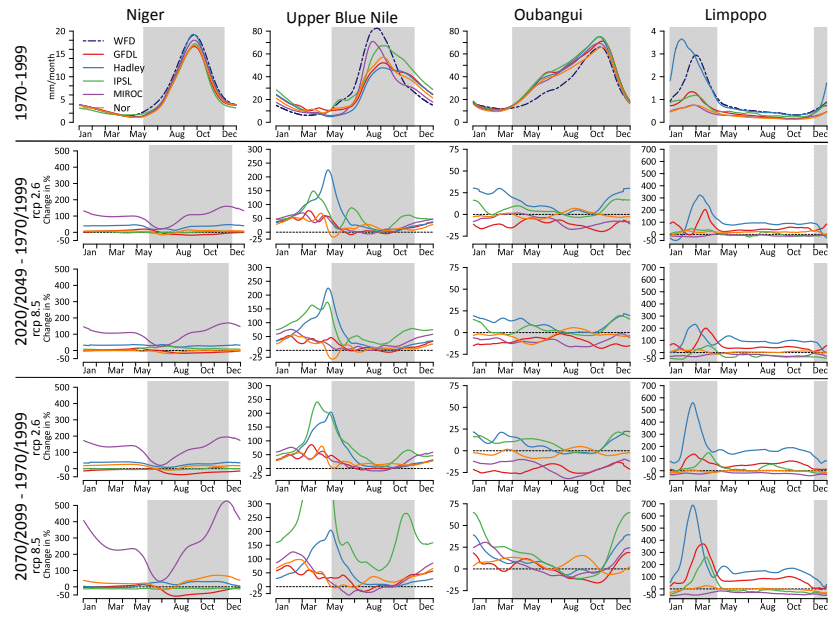

Fig. 8. First row: seasonality of monthly discharge for the reference period; second and third rows: changes in \% of discharge between a near scenario period and reference periods for RCP 2.6 and RCP 8.5; fourth and fifth rows: changes in $\%$ of discharge between a far scenario period and reference periods for RCP 2.6 and RCP 8.5. Recent rainy season as grey shaded area.

shown but are included in the calculation of the fitted local regression, plotted as a black line.

The sensitivity varies distinctly from basin to basin. In the Niger basin, an increase in annual precipitation by $25 \%$ results in an increase in modelled discharge by $\sim 90 \%$, and $25 \%$ less precipitation causes a decrease in annual discharge of almost $50 \%$. In the Upper Blue Nile, a $25 \%$ increase in precipitation leads to $\sim 50 \%$ higher modelled discharge, whereas a $25 \%$ reduction in annual rainfall leads to $\sim 25 \%$ reduction in discharge. In the Oubangui, climate sensitivity is least pronounced; namely, a $25 \%$ increase in precipitation results in less than $30 \%$ increase in annual discharge, and a $25 \%$ decrease reduces discharge by $\sim 40 \%$. In the Limpopo basin sensitivity is highest, and already small changes in the precipitation regime may cause huge effects on the discharge regime. So, a $25 \%$ increase in annual precipitation results in $\sim 125 \%$ higher discharge, and a $25 \%$ reduction in precipitation leads to a decrease in discharge of $\sim 40 \%$. In addition, the spread of impacts in the Limpopo basin is the largest of all four basins.

The response of discharge to rainfall anomalies for the model runs with the observed WFD agrees with the scenario runs in the Niger and the Upper Blue Nile basins. In the Limpopo basin, the form of the curve corresponds to the scenario values, whereas the position shifts. This can be explained by the distribution of rainfall that changes in the scenarios, and rainfall during the dry period becomes more likely (Fig. 5). In the Oubangui basin, the runs with WFD data agree with the scenario runs, though there are some years with an outlying relation of annual precipitation to discharge. This can be explained by a temporal concentration of rainfalls and hence an increased runoff coefficient. 


\subsection{Impact of climate change on discharge and seasonality}

Figure 8 shows mean monthly discharge values or their changes, derived from the daily model output for all four basins and five models in the different time periods and for both RCPs. For the base period (1970-1999), the agreement between the simulated discharge driven by WFD and the five chosen climate models is good for the Niger and Oubangui (Fig. 8, topmost row), yet there are some differences for the Oubangui. However, for the Limpopo and Upper Blue Nile basins the results differ more distinctly. Especially in the Limpopo catchment, only the simulation driven by climate input from one model, HadGEM2-ES, gives results comparable to that driven by the WFD input. However, with regard to the small absolute numbers of discharge in the Limpopo basin, these results are still acceptable.

Regarding the changes in river discharge from the base period to the near (2021-2050) and far (2070-2099) scenario periods, we focus mainly on the rainy season of each basin (Fig. 8, grey shaded area). The spread between the simulations driven by different climate models is high for all basins, ranging from strong increase to little or moderate decrease, depending on basin and climate model (Fig. 7, four lower rows).

For the Niger basin the directions of change differ, which corresponds to the location of the basin in the transition zone of increasing and decreasing precipitation projections of the whole CMIP5 ensemble (Fig. 4). The SWIM model projects changes of monthly discharge when driven by the climate simulation results of Hadley, Nor, IPSL and GFDL for both periods and both RCPs, ranging from an increase of up to $50 \%$ to a decrease of up to $50 \%$. The change in discharge produced with the MIROC climate projections is remarkably higher than that simulated by other climate models. The discharge for the near and far scenario periods increases by the end of the rainy season by $200 \%$ and for the RCP 8.5 in the far period even by $500 \%$.

In the Upper Blue Nile basin, the projections of the SWIM model driven by the five corrected climate models agree almost completely on positive trends which correspond to the precipitation trends shown in Fig. 4. In the near scenario period, there is a slight increase of fluctuations around $0 \%$ at the beginning of the rainy season from June to August for both RCPs. Furthermore, the climate scenarios show an increase at the end of the rainy season. This holds also for the far scenario period, with a slightly stronger increase for the RCP 8.5 at the end of the rainy season. The discharge projections driven by IPSL show the most extreme results, with increases between 50 and $100 \%$ and even $300 \%$ in October of the far period. According to the results obtained, all models including IPSL agree on a shift in peak discharge for both RCPs of around one month.

According to Fig. 7, the Oubangui River is least sensitive to climate variability. This is in line with projections, which show the smallest trends out of all four basins, with the highest increase of discharge up to $60 \%$ in the second period for the RCP 8.5. The projections of the SWIM model driven by the five corrected climate models for both RCPs range from decreases of $15 \%$ to increases up to $20 \%$. However, as the selected climate models in this case do not represent the whole CMIP5 spectrum very well, the validity of this information is limited (Fig. 6).

In the Limpopo basin with its extremely low runoff coefficient and very high sensitivity to climate variability (Fig. 7), the projected trends are the most extreme of all of the four basins. However, analyzing the results in percentage, the small amount of discharge in absolute numbers has to be taken into account, which implies that the annual runoff is still limited. The GFDL-driven model runs show an increase in discharge during the peak of the rainy season of $\sim 200 \%$ in the near period for both RCPs and in the far period for RCP 2.6. The discharge for RCP 8.5 in the far period increases by $350 \%$. The discharge projected with IPSL output also increases by $\sim 50 \%$ in the near period and in the far period by $100 \%$ for RCP 2.6 , and by $200 \%$ for RCP 8.5 . The model output with Nor climate input produces no visible trends for both periods and RCPs. The MIROC model driven runs result in a slightly reduced discharge by $\sim 25 \%$ in the near period and RCP 2.6 in the far period. The projected discharge driven by RCP 8.5 for the far period decreases even up to $50 \%$ in the rainy season. The Hadley-driven simulation produces a striking increase in discharge of $\sim 300 \%$ during the peak of the rainy season in February in the near period for RCP 2.5, and of $\sim 250 \%$ for RCP 8.5 . For the far period, the increase is even more extreme in February at $\sim 550$ and $\sim 700 \%$ for both RCPs.

\subsection{Changes in extremes}

The $Q_{10}$ value is a robust indicator for high flows and designates a value of river discharge which is only exceeded $10 \%$ of the time. A negative trend in $Q_{10}$ means a reduction in flood risk, and a positive trend represents an increase. The results for changes in $Q_{10}$ under scenario conditions are presented in Fig. 9 for two periods and two RCPs.

In the Niger catchment, $Q_{10}$ produced with input from all climate models reflects the direction of changes in mean discharge. The MIROC-driven outputs show a rise in $Q_{10}$ to over $100 \%$ in all four cases. The RCP 8.5 scenario for the far period shows the most extreme increase of over $300 \%$. The outputs driven by all other models show rather moderate changes in $Q_{10}$, which correspond roughly to the percentage of change in the mean discharge during peak flow in the rainy season.

In the Upper Blue Nile basin, the discharge projections for almost all climate models and both RCPs show an increase from $\sim 10 \%$ to $\sim 50 \%$. Only for the RCP 8.5 in the far period, IPSL-driven output projects an increase in $Q_{10}$ of $150 \%$. 

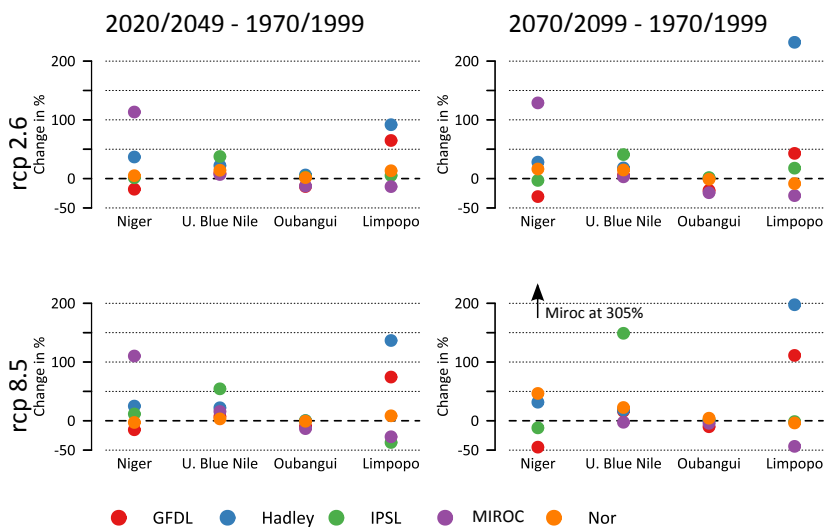

Fig. 9. Change in $Q_{10}$ (high flows) of five bias corrected model projections in near (2020-2049, left column) and far (2070-2099, right column) scenario periods compared to the reference period (1970-1999) for RCP 2.6 (upper row) and RCP 8.5 (lower row) in percent.

The scenarios for the Oubangui produce the lowest $Q_{10}$ trends out of all four basins. An increase in $Q_{10}$ is not projected. The GFDL and MIROC-driven results show a decrease in $Q_{10}$ of $\sim 15 \%$, and the other outputs fluctuate around $0 \%$ for both scenario periods and both RCPs.

In the Limpopo basin, the patterns of changes identified for the mean discharge also hold for $Q_{10}$. The Hadley climatedriven output yields the strongest positive $Q_{10}$ trend of almost $250 \%$ for RCP 2.6 in the far period. For RCP 8.5 the increase is about $200 \%$. In contrast, the increase in the near scenario period is higher for RCP 8.5 at almost $150 \%$ than for RCP 2.6 at $~ 100 \%$. The projections with GFDL input in the near future are almost the same for both RCPs at $\sim 75 \%$. For the far period, the trend reduces to $50 \%$ in the RCP 2.6 case, and for RCP 8.5 it strengthens to $120 \%$. The IPSLdriven projection shows slight increases in both periods for RCP 2.6 and a decrease of almost $50 \%$ in the near period for RCP 8.5. This decrease tends to zero in the far period. The MIROC-driven output shows negative $Q_{10}$ trends for both RCPs in both periods.

A $Q_{90}$ value is used for identifying low flows, indicating that $90 \%$ of the time the value is exceeded (Fig. 10). If the value shows a negative trend, it implicates that low flow is further decreasing and river droughts are likely to occur more often.

In the Niger basin, the $Q_{90}$ trend is mostly positive for both RCPs and both scenario periods. Only GFDL and IPSLdriven outputs show slight negative trends in the far period, between 10 and $20 \%$.

In the Upper Blue Nile basin all trends are positive, showing strong increases. The IPSL-driven simulations again produce extreme results, with increases up to $450 \%$ in the far period for RCP 8.5. The Nor-driven scenarios result in a $Q_{90}$ increase of $\sim 100 \%$ in the far period for both RCPs and $\sim 50 \%$ in the near period for both RCPs. Simulations driven by all

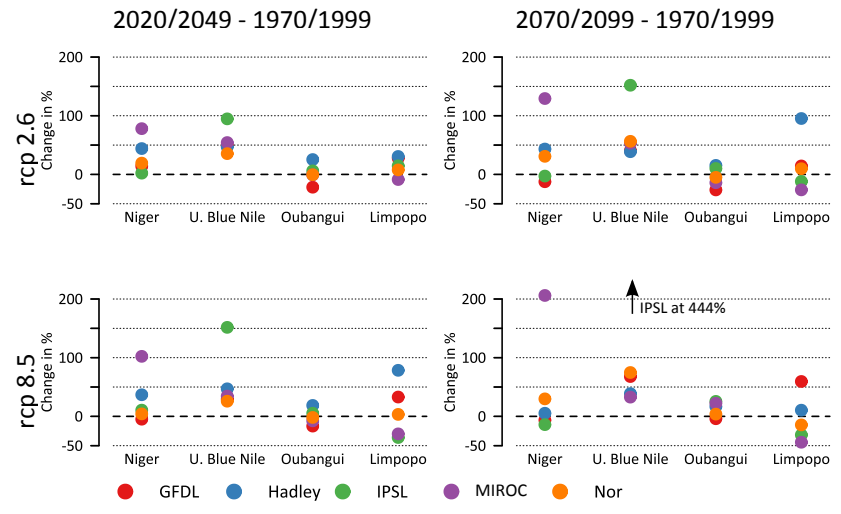

Fig. 10. Change in $Q_{90}$ (low flows) of five bias corrected model projections in near (2020-2049, left column) and far (2070-2099, right column) scenario periods compared to the reference period (1970-1999) for RCP 2.6 (upper row) and RCP 8.5 (lower row) in percent.

other climate models lead to increased $Q_{90}$ trends in a range of 40 to $60 \%$.

In the Oubangui basin, only model runs driven by GFDL and MIROC climate inputs produce a decrease in $Q_{90}$. For GFDL, $Q_{90}$ is reduced by $\sim 25 \%$ for both periods and both RCPs. The MIROC-driven results show a $\sim 20 \%$ decrease in $Q_{90}$ for both RCPs in the near period, a $\sim 25 \%$ decrease for RCP 2.6 in the far period, and almost no trend for RCP 8.5 in the far period. All other simulations produce trends that fluctuate around $0 \%$.

For the Limpopo catchment, MIROC and IPSL climate inputs lead to negative $Q_{90}$ trends. In the near period of RCP 2.6 scenario, only the MIROC climate input leads to a slightly negative trend, whereas for RCP 8.5 the IPSL-driven runs project a decrease of $\sim 15 \%$ and MIROC $\sim 30 \%$. In the far future period, the IPSL and MIROC-driven outputs show a decrease of $\sim$ to $\sim 50 \%$. Simulations driven by the other 3 climate models project a positive $Q_{90}$ trend.

Summarizing the results for changes in extremes, it can be said that the direction of changes identified for the mean discharge holds mostly also for the high and low flow extremes.

\section{Discussion}

The following discussion is structured according to the research objectives presented in the introduction.

\subsection{Differences in climate change sensitivity among the basins}

First aim was to investigate differences in the sensitivity of modelled annual discharge to climate parameters between the basins. The response to changes in precipitation is not a linear process but rather depends on the basin's characteristics. Figure 7 shows that the response to changes in annual 
precipitation is augmented with regard to percent change in streamflow in all basins.

The relationship between changes in precipitation to changes in discharge is most extreme in the Limpopo basin, where we also found the highest probability of major changes to the precipitation regime. This high sensitivity can be explained by the very low runoff coefficient of the Limpopo basin, which makes the catchment very sensitive to changes in precipitation (Table 1). Also for the Upper Blue Nile and Niger basins, the changes in precipitation are likely to intensify the impacts of climate change on discharge in both directions for both drier and wetter years.

These findings are independent of the projected climate scenarios and their uncertainties. Hence, climate change will most likely have significant impacts on river discharge in the Limpopo, even if climate change is more moderate than in other basins studied.

\subsection{Changes of streamflow under climate change}

Our results related to objective (2) on the seasonality of discharge for the four basins in the future mainly confirm the results of former studies on streamflow projections in Africa. Possible decreases in streamflow for the Limpopo, Niger and Oubangui are in the same range (up to $-20 \%$ per year, Fig. 8 ) as in the studies discussed in the introduction. For the Niger basin, the results on increasing streamflow at the downstream part of the river where the Lokoja gauge is located (Table 4) agrees with the findings of other studies (Mahe et al., 2013; Faramarzi et al., 2013). The results for the Oubangui basin are also in line with previous studies, which project varying results with a tendency for decreasing flow as a mean over all projections (De Wit and Stankiewicz, 2006; Strzepek and McCluskey, 2007).

However, the increasing discharge produced for the Upper Blue Nile basin by all climate models and for the Limpopo basin by the majority of the climate projections are partly contradictory to previous studies' results (De Wit and Stankiewicz, 2006; Strzepek and McCluskey, 2007) and also to the African chapter of the Fourth Assessment Report of the IPCC (AR4) (Boko et al., 2007). Especially for the Upper Blue Nile basin, simulations driven by all climate input runs chosen resulted in higher annual discharge, on average even up to $40 \%$ for the first half of the 21 st century. However, also for the Limpopo basin where other studies projected decreases in streamflow (Zhu and Ringler, 2012; De Wit and Stankiewicz, 2006), the multi-model mean of the climate models resulted in an increase of mean annual streamflow for both scenario periods with a high agreement for the first half of the century at RCP 2.6. As both previous studies focused on the continental scale on a defined grid, it is difficult to compare the outputs directly.

Regarding the differences between RCP 2.6 and 8.5, our findings agree with the observations of the AR4, which states that the differences between the emission scenarios mainly take effect in the second half of the 21st century (Solomon et al., 2007). This holds for all four basins. The projections of increasing streamflow in the basins are especially remarkable as in all catchments a substantial increase of temperature (Fig. 5) and hence potential evapotranspiration is projected, which would lead under constant rainfall to a reduction of streamflow. In the Oubangui basin it can be seen exemplarily that the increase of rainfall in the climate models does not automatically lead to an increase of discharge but the increase in evapotranspiration leads to a decrease of streamflow despite increasing rainfall. This is in line with other studies in this basin (Tshimanga and Hughes, 2012).

\subsection{Changes in hydrological extremes}

Results with regard to research question (3) on changes in hydrological extremes affirm the occurrence of trends found previously. Concerning flood risk in Africa at the continental scale or for large regions in Africa, most previous assessments focused on changing vulnerability (Di Baldassarre et al., 2010; Mngutyo, 2012; Tschakert et al., 2010; Hastenrath et al., 2010) and less on climate change. However, a recent study by Jury (2013) found a return to wet conditions throughout Africa in the period 1995-2010 by means of trends in monthly river flow records, meteorological reanalysis data, and satellite observations. This tendency of increasing high flows in the observations matches our findings in all basins studied except the Oubangui basin (Figs. 9, 4). However, the Oubangui basin modelling has shown a substandard efficiency in terms of high flows in the PBIAS criteria and the projections of decreasing or stable high flows should be interpreted carefully. Still the performance of the model in the other basins in terms of high flows during the validation, especially in the Niger basin and the Upper Blue Nile basin, was good and the increase of high flows holds especially for the Upper Blue Nile basin, where simulations driven by all climate models resulted in a distinct increase in high flows for both RCPs and both scenario periods.

Our study also shows that climate change might play a major role in the increasing risk of hazardous floods in Africa. For a few model runs, these trends are extreme, especially for the Limpopo and the Niger. For the Oubangui basin, the model results agree on a relatively low change in high floods and show discrepancies in the direction of the trend. As flood risk is caused not only by a higher frequency or amplitude of the hazard itself, but is also linked to a rising vulnerability in sub-Saharan Africa, flood hazards should be taken into account when assessing climate change impacts and adaptation in Africa.

When it comes to low flows, the existing literature agrees mostly on an increase of frequency and magnitude of river droughts throughout the African continent (e.g. Boko et al., 2007; Faramarzi et al., 2013). These findings are not always connected to climate change, but to the increase in water use. As we focus on climate change and neglect changes in land 
Table 4. Summary of modelling results.

\begin{tabular}{|c|c|c|c|c|c|c|}
\hline & \multicolumn{6}{|c|}{ Change between 2020-2049 and 1970-1999 (RCP 2.6/8.5) ${ }^{\mathrm{a}}$} \\
\hline & \multicolumn{3}{|c|}{ Direction of trend in $\%^{b}$} & \multicolumn{3}{|c|}{ Mean amount of change in $\%$} \\
\hline & Mean & $Q_{10}$ & $Q_{90}$ & Mean & $Q_{10}$ & $Q_{90}$ \\
\hline Niger & $60 / 60$ & $80 / 60$ & $<50 / 60$ & $28 / 27$ & $32 / 30$ & $28 / 26$ \\
\hline U. Blue Nile & $100 / 100$ & $100 / 100$ & $100 / 80$ & $38 / 40$ & $56 / 57$ & $18 / 21$ \\
\hline Oubangui & $<50 /<50$ & $<50 /<50$ & $<50 /<50$ & $0 /-2$ & $2 / 0$ & $-3 /-5$ \\
\hline \multirow[t]{4}{*}{ Limpopo } & $80 / 60$ & $80 /<50$ & $80 / 60$ & $34 / 23$ & $14 / 10$ & $32 / 31$ \\
\hline & \multicolumn{6}{|c|}{ Change between 2070-2099 and 1970-1999 } \\
\hline & \multicolumn{3}{|c|}{ Direction of trend in $\%$} & \multicolumn{3}{|c|}{ Mean change in $\%$} \\
\hline & Mean & $Q_{10}$ & $Q_{90}$ & Mean & $Q_{10}$ & $Q_{90}$ \\
\hline Niger & $60 / 60$ & $60 / 60$ & $60 / 60$ & $30 / 56$ & $38 / 44$ & $28 / 65$ \\
\hline U. Blue Nile & $100 / 100$ & $100 / 100$ & $80 / 80$ & $44 / 81$ & $68 / 132$ & $16 / 41$ \\
\hline Oubangui & $<50 / 80$ & $>50 / 60$ & $<50 /<50$ & $-5 / 7$ & $-4 / 12$ & $-9 /-2$ \\
\hline Limpopo & $60 / 60$ & $60 / 60$ & $60 / 60$ & $48 / 53$ & $16 /-4$ & $51 / 52$ \\
\hline
\end{tabular}

${ }^{\text {a }}$ Changes in annual mean discharge above $5 \%$ or under $-5 \%$ have been counted as positive/negative. Less than a $5 \%$ trend was counted as no trend. ${ }^{b}$ Percent values have been calculated by comparing the five corresponding model runs driven by the chosen climate projections.

use, it is difficult to compare the results. However, the mean changes in $Q_{90}$ are positive for the Niger basin, Upper Blue Nile basin and Limpopo basin (Table 4). In regard of the deficiencies in terms of PBIAS during the low flows in the Upper Blue Nile basin, these results should be interpreted with caution also when looking on relative changes. In the Limpopo basin, where previous studies mainly agreed on an increase of hydrological droughts (Zhu and Ringler, 2012), our results driven by three of the five climate model outputs show a positive tendency for the low flow level, which means a reduced likelihood of riverine droughts (Fig. 10). In the Niger basin, where droughts are also an issue (Oguntunde and Abiodun, 2013), the $Q_{90}$ trend is mostly positive, and only results driven by two climate models show slightly negative trends. Only for the Oubangui basin do the results indicate an increased likelihood of low flows, but with a very high degree of uncertainty (based on results driven by only two climate models). Hence, taking climate change into account, our study with the five chosen climate projections does not support the widespread view of a distinctly higher probability of decreasing low flows for these regions in Africa.

\subsection{Sources of uncertainties}

Our research objective (4) focuses on the sources of uncertainty in this climate impact study. As with the first finding, we see a broad range of projected changes in precipitation in the five chosen ESMs in each basin, and the associated uncertainties are striking for the near future but even greater for the far future (Fig. 4). In contrast, the analysis shows that the direction of the temperature trend on the African continent is confirmed by all CMIP5 models; the temperature change in the four basins ranges from 3 to $6^{\circ} \mathrm{C}$ until the end of the century under RCP 8.5 (Fig. 5). Hence, the uncertainty in terms of streamflow, which is largely influenced by both, temperature and precipitation, derives mainly from uncertainties in precipitation. This uncertainty could not be reduced with the bias correction method used.

For the Niger, Oubangui and Limpopo there is one climate model for each that produces outlying results that should be interpreted with particular caution when discussing the impacts. The MIROC model for the Niger and the IPSL model for the Upper Blue Nile show outlying increases in discharge, distinctly different from the other results. These extreme increases can be explained by the extreme increase in precipitation, produced by the bias correction of the climate output using the method of Hempel et al. (2013) (Fig. 6). In the Limpopo basin, the extreme discharge resulting from the simulation driven by the Hadley model can be explained by extremely high rainfall. The high sensitivity to weather extremes in the Limpopo basin most often results in the very high discharge peaks (Table 1; Fig. 9). However, in the Limpopo basin not only the uncertainties originating from the climate models are high but also the performance of the hydrological model for peak discharges is rather weak (Fig. 3).

The uncertainties derived from the climate model runs are propagated in the cascade of uncertainty to the hydrological model, resulting in the broad range of changes in discharge for each basin. Here, the intercomparison of model set-ups and validation results among the four basins confirmed the dependency of model performance on availability and quality of the input data. With increasing basin size, the data requirements grow, but even more influential are the basins' 
characteristics in terms of heterogeneity and complexity, including water management, wetlands, etc. Nevertheless, as the performance of the SWIM model is adequate for all basins, the hydrological model probably plays a minor role in this uncertainty. This assumption is supported by the small differences between river discharge amounts simulated with the WFD climate input and the climate models' input during the reference period. Especially in areas with very low runoff coefficient and high sensitivity as in the Limpopo basin, the model is very sensitive to climate input and the requirements for consistent and reliable climate scenarios are very high.

\subsection{Implications for adaptation}

The final research question takes a broader view and looks at the general suitability of a regional intercomparison in order to assess adaptation. Compared to literature reviews in which the comparison of results is usually hampered by the differences between the applied models, scenario assumptions and periods applied, a regional impact comparison study as shown here gives more coherent and comparable results. This holds for the mean changes as well as for the ranges of uncertainty with which they are affected.

As far as adaptation is concerned, we are able to distinguish two types of uncertainty in our results: in one case, the simulations driven by the climate models agree on the direction of the trend. This is mostly the case for the Upper Blue Nile basin, where the trend agreement for the mean, $Q_{10}$ and $Q_{90}$ was far higher than in the other catchments (Table 4). In other cases, they do not even agree on the trend's direction. For the purposes of adaptation, the latter case seems to be the most difficult to react to. Regarding an agenda for adaptation, this might be a factor for decision making where impact comparisons may be involved. In addition, the magnitude of change for high flows is the highest in the Upper Blue Nile basin, and additional studies could focus on this particular issue.

In terms of adaptation planning in Africa, there is additional information that can be derived from the comparison. For all four basins, basin-wide action plans for water management (and in many of the riparian states, the additional national plans as well) exist or are in development (Niger: Niger Basin Authority, 2007; Upper Blue Nile: Block et al., 2007; Oubangui: Commission Internationale du Bassin Congo-Oubangui-Sangha, 2007; Limpopo: UN Habitat and UNEP, 2007). These plans all include adaptation to climate change in the water sector. However, due to the overwhelming threat of droughts and water scarcity in many regions of Africa, all of these plans account mainly or solely for decreasing streamflow and river droughts. In our study, we show that in the Niger, Upper Blue Nile and Limpopo the risk of high flows will increase. Of course, these results have to be interpreted carefully, as our projections are driven by five bias corrected climate models that do not cover the entire range of the whole CMIP5 ensemble (Fig. 5), and uncer- tainty in the projections is still unavoidable even if the whole ensemble were to be used. Still, disastrous floods in the past decades in many parts of Africa have shown that these catastrophes represent one of the main challenges and an increasing threat under global change in many regions in Africa (e.g. Jury, 2013; Di Baldassarre and Uhlenbrook, 2012; Di Baldassarre et al., 2010). Our findings support this perception and underpin the need for broad adaptation strategies, taking projections for future flooding into account.

However, in the face of these high uncertainties deriving mainly from the climate projections, adaptation is very challenging. Recent studies argue for a "bottom-up" approach to reduce vulnerability instead of adapting "top-down" on the basis of uncertain projections (Richardson et al., 2011; FEW et al., 2007). Also, with state-of-the-art climate projections and modelling approaches, these conclusions cannot be disproved and uncertainties reduced. Still, a comparison of climate change impacts on river discharge and their uncertainties, even using a very general and basic approach, may support decision makers in answering the challenges of climate change.

\section{Summary and conclusions}

The differences between the sensitivities of streamflow regimes to climate variability among the four basins studied are remarkably large; the Limpopo basin with the lowest runoff coefficient being the most sensitive. With regard to future changes in quantity and seasonality of streamflow, we show that the most extreme changes in discharge are likely to happen in the Upper Blue Nile catchment. Here, all climate model projections result in increased streamflow and an extension of the streamflow peaks at the beginning and end of the rainy season. In the Niger and Limpopo basins, the direction of the trend is unclear, whereas the magnitude of change is large for simulations driven by single climate models. In contrast, impacts on the Oubangui River are not so significant compared to others, but still do not all lead in the same direction. In general, this also holds for the extremes. In the Upper Blue Nile basin, there is a clear picture of increasingly high flows for all model runs and a reduction of risk for low flows. For the Limpopo and Niger the trends are diverse, but the majority of runs project increasingly high flows and higher low flows (reduction of risk for low flows). In the Oubangui, the trend for the extremes is unclear and the magnitude of changes is less significant.

In terms of uncertainty, our results confirm that the most uncertainty in regional impact studies derives from climate models, even if the input is bias corrected. In our case, an improvement in the regional hydrological model's performance seems unlikely to diminish uncertainties in streamflow projections substantially, due to the huge range of uncertainty deriving from the climate models' projections. In order to identify and quantify the whole cascade of uncertainty, 
communication between regional impact modellers and regional climate modellers should be intensified. Particularly the efforts toward improvement of bias correction methods of the climate model outputs should be strengthened.

These broad uncertainty ranges, in which the probabilities of trend directions are in some cases even equally distributed, are of little use for planning actual adaptation measures. Moreover, it should be noted that only five bias corrected ESMs were applied in our study, and a larger number of climate projections would most likely have resulted in an even broader range of uncertainty (Fig. 5). However, some robust trends still can be detected:

- The direction of trends for the Upper Blue Nile basin is almost uniform, and our results clearly suggest an increase in discharge and high flows. This strongly indicates that water management in this region should adapt to a longer and more intense rainy season and more intense and frequent flooding in the future.

- The agreement of the projections on increasingly high flows in three of the four regions (except the Oubangui) is remarkable. It agrees with many studies on increased flood frequency and amplitude in past decades in many rivers (e.g. Jury, 2013; Di Baldassarre and Uhlenbrook, 2012; Di Baldassarre et al., 2010). Adaptation efforts in Africa should consider this threat, even if water scarcity is still the main challenge in most of the African regions.

For the Niger and the Limpopo, the diversity of projected trends in average runoff suggests a need for implementation of a wider range of possible adaptation measures. In both cases, our results imply that the focus of adaptation strategies should be broad and include a general reduction of vulnerability of the riverine population. In the Oubangui basin, the trends are unclear and more moderate, which would imply a lower priority level for climate change adaptation for this catchment.

Still, the results should be interpreted carefully, not only because the uncertainties are remarkably high. For very large basins such as the Niger, future studies should also consider the main sub-regions in order to be able to compare impacts for different climate zones. In addition, detailed future studies for planning adaptation strategies have to consider the need for development of flood protection measures.

\section{Supplementary material related to this article is available online at http://www.hydrol-earth-syst-sci.net/ 18/1305/2014/hess-18-1305-2014-supplement.pdf.}

Acknowledgements. We thank the IMPACT2c project for financing this study and ISI-MIP for providing us with bias corrected climate scenarios.

Edited by: D. Mazvimavi

\section{References}

Andersen, I.: The Niger River Basin: a Vision for Sustainable Management, World Bank Publications, available at: http://siteresources.worldbank.org/INTWAT/Resources/ 4602114-1206643460526/Niger_River_Basin_Vision_

Sustainable_Management.pdf (last access: 8 February 2013), 2005.

Arnold, J. G., Allen, P. M., and Bernhardt, G.: A comprehensive surface-groundwater flow model, J. Hydrol., 142, 47-69, 1993.

Ashton, P., Love, D., Mahachi, H., and Dirks, P.: An Overview of the Impact of Mining and Mineral Processing Operations on Water Resources and Water Quality in the Zambezi, Limpopo and Olifants Catchments in Southern Africa, Contract Report to the Mining, Minerals and Sustainable Development (SOUTHERN AFRICA) Project, by CSIR-Environmentek, Pretoria, South Africa and Geology Department, University of Zimbabwe, Harare, Zimbabwe, 2001a.

Ashton, P., Love, D., Mahachi, H., and Dirks, P.: Impacts of Mining and Mineral Processing on Water Resources in the Zambezi, Limpopo, and Olifants Catchment, Powerpoint Presentation by CSIR Environmentek Pretoria, South Africa and Geology Department, University of Zimbabwe, Harare, Zimbabwe, 32 pp., $2001 b$.

Awulachew, S. B., Loulseged, A. D., Loiskandl, M., Ayana, W., and Alamirew, T.: Water Resources and Irrigation Development in Ethiopia, International Water Management Institute, Colombo, Sri Lanka, 2007.

Bartholomé, E. and Belward, A. S.: GLC2000: a new approach to global land cover mapping from Earth observation data, Int. J. Remote Sens., 29, 1959-1977, 2005.

Block, P. J., Strzepek, K., and Rajagopalan, B.: Integrated Management of Blue Nile Basin in Ethiopia: Hydropower and Irrigation Modeling, IFPRI Discussion Paper 00700, available at: http: //water.columbia.edu/files/2011/11/Block2007Integrated(1).pdf (last access: 29 October 2013), International Food Policy Research Institute (IFPRI), Washington, D.C., USA, 23 pp., 2007.

Boko, M., Niang, I., Nyong, A., Vogel, C., Githeko, A., Medany, M., Osman-Elasha, B., Tabo, R., and Yanda, P.: Africa, in: Climate Change 2007: Impacts, Adaptation and Vulnerability. Contribution Of Working Group II to the Fourth Assessment Report of the Intergovernmental Panel on Climate Change (IPCC), edited by: Parry, M. L., Canziani, O. F., Palutikof, J. P., Linden, P. J., and van der and Hanson, C. E., available at: http://cgspace.cgiar. org/handle/10568/17019 (last access: 27 June 2013), Cambridge University Press, 433-467, 2007.

Commission Internationale du Bassin Congo-OubanguiSangha: Plan d'Action Stratégique, available at: http: //www.cicos.info/siteweb/uploads/media/1.1._Amelioration du_Plan_d_Action_Strategique_PAS_.pdf (last access: 29 October 2013), 2007.

Conway, D.: The climate and hydrology of the Upper Blue Nile River, Geogr. J., 166, 49-62, 2000.

De Wit, M. and Stankiewicz, J.: Changes in surface water supply across Africa with predicted climate change, Science, 311, 19171921, 2006.

Di Baldassarre, G. and Uhlenbrook, S.: Is the current flood of data enough? A treatise on research needs for the improvement of flood modelling, Hydrol. Process., 26, 153-158, 2012. 
Di Baldassarre, G., Montanari, A., Lins, H., Koutsoyiannis, D., Brandimarte, L., and Blöschl, G.: Flood fatalities in Africa: from diagnosis to mitigation, Geophys. Res. Lett., 37, L22402, doi:10.1029/2010GL045467, 2010.

FAO: Drought Impact Mitigation and Prevention in the Limpopo River Basin: a Situation Analysis, FAO Sub-Regional Office for Southern and East Africa, Harare, 2004.

FAO, IIASA, ISRIC, ISSC and JRC: Harmonized World Soil Database $\mathrm{v}$ 1.2, available at: http://webarchive.iiasa.ac.at/ Research/LUC/External-World-soil-database/HTML/ (last access: 26 June 2013), 2012.

Faramarzi, M., Abbaspour, K. C., Ashraf Vaghefi, S., Farzaneh, M. R., Zehnder, A. J. B., Srinivasan, R., and Yang, H.: Modeling impacts of climate change on freshwater availability in Africa, J. Hydrol., 480, 85-101, 2013.

Few, R., Brown, K., and Tompkins, E. L.: Public participation and climate change adaptation: avoiding the illusion of inclusion, Clim. Policy, 7, 46-59, 2007.

Fekete, B. M., Vorosmarty, C. J., and Grabs, W.: Global, composite runoff fields based on observed river discharge and simulated water balances, GRDC Report 22, Global Runoff Data Center, Koblenz, Germany, 1999.

Frenken, K. and Faurès, J. M.: Irrigation Potential in Africa: a Basin Approach, FAO, Rome, 1997.

Hargreaves, G. H. and Samani, Z. A.: Estimating potential evapotranspiration, J. Irr. Drain. 108, 225-230, 1982.

Hastenrath, S., Polzin, D., and Mutai, C.: Diagnosing the droughts and floods in Equatorial East Africa during boreal autumn 200508, J. Climate, 23, 813-817, 2010.

Hempel, S., Frieler, K., Warszawski, L., Schewe, J., and Piontek, F.: A trend-preserving bias correction - the ISI-MIP approach, Earth Syst. Dynam., 4, 219-236, doi:10.5194/esd-4-219- 5 2013, 2013.

Jarvis, A., Reuter, H. I., Nelson, A., and Guevara, E.: Hole-filled SRTM for the globe Version 4, available at: http://srtm.csi.cgiar. org/ (last access: 2 March 2013), 2008.

Jury, M. R.: A return to wet conditions over Africa: 1995-2010, Theor. Appl. Climatol., 111, 471-481, 2013.

Koch, H., Liersch, S., and Hattermann, F. F.: Integrating water resource managing in ecohydrological modelling, Water Sci. Technol., 67, 1525-1533, 2013.

Köppen, W.: Versuch einer Klassifikation der Klimate, vorzugsweise nach ihren Beziehungen zur Pflanzenwelt, Geogr. Zeitschrift, 6, 593-611, 1900.

Krysanova, V., Meiner, A., Roosaare, J., and Vasilyev, A.: Simulation modelling of the coastal waters pollution from agricultural watershed, Ecol. Model., 49, 7-29, 1989.

Krysanova, V., Müller-Wohlfeil, D.-I., and Becker, A.: Development and test of a spatially distributed hydrological/water quality model for mesoscale watersheds, Ecol. Model., 106, 261-289, 1998.

Krysanova, V., Arnold, J. G., Wechsung, F., Srinivasan, R., and Williams, J.: SWIM (Soil and Water Integrated Model) Users Manual, Potsdam Institute for Climate Impact Research, Potsdam, Germany, 2000.

Krysanova, V., Hattermann, F., and Wechsung, F.: Development of the ecohydrological model SWIM for regional impact studies and vulnerability assessment, Hydrol. Process., 19, 763-783, 2005.
LBPTC: Joint Limpopo River Basin Study Scoping Phase, Final Report, BIGCON Consortium, Maputo, Mozambique, 2010.

Liersch, S., Cools, J., Kone, B., Koch, H., Diallo, M., Reinhardt, J., Fournet, S., Aich, V., and Hattermann, F. F.: Vulnerability of rice production in the Inner Niger Delta to water resource managing under climate variability and change, Environ. Sci. Policy, 25, 18-33, doi:10.1016/j.envsci.2012.10.014, 2013.

Mahe, G., Lienou, G., Descroix, L., Bamba, F., Paturel, J. E., Laraque, A., Meddi, M., Habaieb, H., Adeaga, O., Dieulin, C., Chahnez Kotti, F., and Khomsi, K.: The rivers of Africa: witness of climate change and human impact on the environment, Hydrol. Process., 27, 2105-2114, 2013.

Mngutyo, A.: An Investigation of the Influence of the Flooded Household Environments on Maternal Health of Flood Plain Dwellers in Makurdi, OIDA Int. J. Sustain. Develop., 4, 29-38, 2012.

Nash, J. E. and Sutcliffe, J. V.: River flow forecasting through conceptual models part I - a discussion of principles, J. Hydrol., 10, 282-290, 1970.

Niger Basin Authority (NBA): Master Plan for the Development and Management of the Niger River Basin, available at: http://www.abn.ne/images/documents/textes/padd/phase_2_ en.pdf (last access: 20 October 2013), 2007.

NWP: Summary Note of the Nairobi Work Programme on Impacts, Vulnerability and Adaptation to Climate Change, in: Fifth Focal Point Forum, Durban, South Africa, UNFCC, available at: http://www.unfccc.int/adaptation/workstreams/nairobi_ work_programme/items/3633.php (last access: 29 June 2013), 2011.

Ogilvie, A., Mahé, G., Ward, J., Serpantié, G., Lemoalle, J., Morand, P., Barbier, B., Tamsir Diop, A., Caron, A., Namarra, R., Kaczan, D., Lukasiewicz, A., Paturel, J.-E., Liénou, G., and Charles Clanet, J.: Water, agriculture and poverty in the Niger River Basin, Water Int., 35, 594-622, 2010.

Oguntunde, P. G. and Abiodun, B. J.: The impact of climate change on the Niger River Basin hydroclimatology, West Africa, Clim. Dynam., 40, 81-94, 2013.

Richardson, K., Steffen, W., and Liverman, D.: Climate Change: Global Risks, Challenges and Decisions, Cambridge University Press, 2011.

Rogelj, J., Meinshausen, M., and Knutti, R.: Global warming under old and new scenarios using IPCC climate sensitivity range estimates, Nat. Clim. Change, 2, 248-253, doi:10.1038/nclimate1385, 2012.

Salman, S. M. A.: The Nile Basin Cooperative Framework Agreement: a peacefully unfolding African spring?, Water Int., 38, 1729, 2013.

Schneider, U., Becker, A., Finger, P., Meyer-Christoffer, A., Ziese, M., and Rudolf, B.: GPCC's new land surface precipitation climatology based on quality-controlled in situ data and its role in quantifying the global water cycle, Theor. Appl. Climatol., 115, 15-40, doi:10.1007/s00704-013-0860-x, 2014.

Shanin, M.: Hydrology and Water Resources of Africa, Springer, New York, Boston, Dordrecht, London, Moscow, 2002. 
Solomon, S., Qin, D., Manning, M., Alley, R. B., Berntsen, T., Bindoff, N. L., Chen, Z., Chidthaisong, A., Gregory, J. M., Hegerl, G. C. Heimann, M., Hewitson, B., Hoskins, B. J., Joos, F., Jouzel, J., Kattsov, V., Lohmann, U., Matsuno, T., Molina, M., Nicholls, N., Overpeck, J., Raga, G., Ramaswamy, V., Ren, J., Rusticucci, M., Somerville, R., Stocker, T. F., Whetton, R., Wood, P. A., and Wratt, D.: Technical Summary, in: Climate Change 2007: The Physical Science Basis, Contribution of Working Group I to the Fourth Assessment Report of the Intergovernmental Panel on Climate Change, edited by: Solomon, S., Qin, D., Manning, M., Chen, Z., Marquis, M., Averyt, K. B., Tignor, M., and Miller, H. L., available at: http://www.ipcc.ch/pdf/assessment-report/ar4/ wg1/ar4-wg1-ts.pdf (last access: 29 October 2013), Cambridge University Press, Cambridge, UK and New York, NY, USA, 2007.

Strahler, A.: Introducing Physical Geography, Wiley, 664 pp., 2013.

Strzepek, K. and McCluskey, A.: The Impacts of Climate Change on Regional Water Resources and Agriculture in Africa, World Bank Policy Research Working Paper 4290, available at: http:// papers.ssrn.com/sol3/papers.cfm?abstract_id=1004404 (last access: 27 June 2013), 2007.

Tshimanga, R. M.: Hydrological uncertainty analysis and scenario based streamflow modelling for the Congo River Basin. PhD thesis, Rhodes University repository, South Africa, 2012.

Tshimanga, R. M. and Hughes, D. A.. Climate change and impacts on the hydrology of the Congo Basin: the case of the northern sub-basins of the Oubangui and Sangha Rivers, Phys. Chem. Earth, 50-52, 72-83, 2012.

Tschakert, P., Sagoe, R., Ofori-Darko, G., and Codjoe, S.: Floods in the Sahel: an analysis of anomalies, memory, and anticipatory learning, Clim. Change, 103, 471-502, 2010.

UN: Water in a ChangingWorld, The United NationsWorldWater Development Report 3, World Water Assessment Programme, available at: http://webworld.unesco.org/water/wwap/ wwdr/wwdr3/tableofcontents.shtml (last access: 29 October 2013), 2009.
UN-HABITAT/UNEP: Limpopo Basin Strategic Plan for Reducing Vulnerability to Floods and Droughts, Draft for Discussion with Riparian Governments, available at: http://www.limpoporak.com/_system/DMSStorage/3471en/ UNEP_UN\%20Habitat_GEF2007_Limpopo\%20Basin\% 20Strategic\%20Plan\%20(low\%20res).pdf (last access: 29 October 2013), 2007.

Vanden Bossche, J.-P. and Bernacsek, G. M.: Source Book for the Inland Fishery Resources of Africa, FAO, Rome, 1990.

Van Vuuren, D. P., Edmonds, J., Kainuma, M., Riahi, K., Thomson, A., Hibbard, K., Hurtt, G. C., Kram, T., Krey, V., and Lamarque, J.-F.: The representative concentration pathways: an overview, Clim. Change, 109, 5-31, 2011a.

Van Vuuren, D. P., Stehfest, E., Elzen, M. G. J., Kram, T., Vliet, J., Deetman, S., Isaac, M., Klein Goldewijk, K., Hof, A., Mendoza Beltran, A., Oostenrijk, R., and Ruijven, B.: RCP2.6: exploring the possibility to keep global mean temperature increase below 2 C, Clim. Change, 30109, 95-116, doi:10.1007/s10584011-0152-3, 2011b.

Weedon, G. P., Gomes, S., Viterbo, P., Shuttleworth, W. J., Blyth, E., Österle, H., Adam, J. C., Bellouin, N., Boucher, O., and Best, M.: Creation of the WATCH forcing data and its use to assess global and regional reference crop evaporation over land during the twentieth century, J. Hydrometeorol., 12, 823-848, 2011.

Wesselink, A. J., Orange, D., and Feizouré, C. T.: Les Régimes Hydroclimatiques et Hydrologiques d'un Bassin Versant de Type Tropical Humide: l'Oubangui (République Centrafricaine), in: L'hydrologie Tropicale: Géoscience et Outil pour le Développement, edited by: Chevallier, P. and Pouyaud, B., IAHS Publication, Wallingford, UK, 179-194, 1996.

WFD: EU WATCH - Home, available at: http://www.eu-watch. org/templates/dispatcher.asp?page_id=25222705 (last access: 7 February 2013), 2011.

WRDC: World Radiation Data Centre, available at: http:// wrdc-mgo.nrel.gov/ (last access: 16 May 2013), 2000.

Zhu, T. and Ringler, C.: Climate change impacts on water availability and use in the Limpopo River Basin, Water, 4, 63-84, 2012. 